\title{
Insulin-Like Growth Factor-Binding Protein 1
}

National Cancer Institute

\section{Source}

National Cancer Institute. Insulin-Like Growth Factor-Binding Protein 1. NCI Thesaurus.

Code $C 17505$.

Insulin-like growth factor-binding protein 1 (259 aa, $28 \mathrm{kDa}$ ) is encoded by the human IGFBP1 gene. This protein is involved in cell migration and both insulin-like growth factor binding and signaling. 